\title{
УДК 005.95/96:004
}

\section{ДІДЖІТАЛІЗАЦІЯ НR-ПРОЦЕСІВ У СУЧАСНИХ РЕАЛІЯХ}

\section{Наталія Данилевич; Світлана Рудакова; Людмила Щетініна; Ярослав Касяненко}

\author{
ДВНЗ «КНЕУ імені Вадима Гетьмана», Київ, Украӥна
}

\begin{abstract}
Резюме. Проаналізовано тендениії процесу діджіталізаџіï служби управління персоналом, вивчення їх головних можливостей та ризиків, оскільки є необхідність вивчення ризиків та можливостей впровадження різних інструментів діджіталізачії в діяльність НR-служби. За результатами проведеного опитування головними перевагами на думку респондентів є: скорочення витрат часу на типові кадрові прочедури, забезпечення прозорості кадрових прочесів, спрощення взаємодії співробітників, інтеграція з різними інформаційними системами та веб-ресурсами, розвиток НR-бренду компанії, економія кочтів завдяки автоматизації, відстеження процесів адаптації, розвиток та професійне зростання співробітників, деталізованість $i$ точність даних. НR-прочеси нині автоматизуються за допомогою різноманітних ициррових рімень. У досліджені визначено різні програми та системи, починаючи з програми для проведення відеоконференцій «Zоот» $i$ закінчуючи HRMсистемами, такими, як «SAP HCM» та «Oracle HCM». Вони є привабливими завдяки їх простоті, можливості інтеграції з іншими системами та через невисоку ціну. Але не можна визначити універсальні діджітал-технології та інструменти для всіх організацій. Для кожної окремої організації можуть застосовуватися тільки ті, які корисні в умовах їі розвитку та існування. Необхідно поєднувати різні підходи й методи. Це дозволить організачії оптимізувати НR-прочеси. Водночас, діджіталізачія вимагає грошових витрат $і$ часу. Кожен HR повинен пери за все визначити свою роль, яка допоможе керівництву та працівникам швидко трансформуватися й адаптуватися до ијифрового способу мислення. Саме від HR-служби залежить продуктивність праці колективу і як наслідок - компанї в иілому. Сучасний HR за допомогою різноманітних цифррових рішень створює для працівників середовище для ефективної та продуктивної праці. Досвід проведення провідними компаніями діджіталізаціi НR-функцій доводить свою ефективність. Однак імплементація різних ї̈ методів і підходів, а також оцінювання їх ефективності потребує подальшого дослідження.
\end{abstract}

Ключові слова: автоматизачія, діджітацізація, цฺифровізація, НR-служба, ичифрові технологї.

https://doi.org/10.33108/galicianvisnyk_tntu2020.03.147

Отримано 17.04.2020

\section{UDC 005.95/96:004}

\section{HR-PROCESSES DIGITIZATION IN PRESENT-DAY DEVELOPMENTS}

\section{Nataliia Danylevych; Svetlana Rudakova; Lyudmila Shchetinina; Yaroslav Kasianenko}

\section{SHEI «Kyiv NationalEconomicUniversity named after Vadym Hetman», Kyiv, Ukraine}

\begin{abstract}
Summary. The objective of the paper is to analyze the trends of digitization process of personnel management service, to investigate their main capabilities and risks since it is necessary to examine the risks and opportunities for the implementation of different digitization tools in HR-service activity. The results of the conducted poll show that the main advantages of digitization are: the reduction of time spent on standard personnel management procedures, ensuring transparency of personnel management processes, simplifying the employees interaction, integration with various information systems and web-resources, development of the
\end{abstract}


company HR-brand, cost savings due to automation, adaptation processes tracking, development and professional growth of employees, data specification and accuracy. At present HR-processes are automated due to various digital solutions. In our investigation, various programs and systems, starting from the video conferencing program «Zoom» up to HRM systems such as «SAP HCM» and «Oracle HCM» are analyzed. They are attractive owing to their simplicity, ability to integrate with other systems and because of their low cost. However it is not possible to define universal digital technologies and tools for all organizations For each individual organization, only those digital technologies which are useful in its development and existence conditions can be applied. It is necessary to combine different approaches and methods, making it possible for the organization to optimize HRprocesses. At the same time, digitization requires both money and time. At present every HR should first and foremost define the role that will help executives and employees to transform and adapt quickly to the digital way of thinking. It is HR-service that determines the productivity of the team and, as a result, of the company as a whole. By means of various digital solutions, modern HR creates the environment for employees where they work efficiently and productively. The leading companies experience in HR functions digitization proves its effectiveness. However, the implementation of its various methods and approaches, as well as the evaluation of their effectiveness, requires further investigations.

Key words: automation, digitization, HR-service, digital technologies.

https://doi.org/10.33108/galicianvisnyk_tntu2020.03.147

Received 17.04.2020

Постановка проблеми. Нині ринок праці динамічно розвивається, кидаючи бізнесу i HR-службі нові виклики. Якщо раніше виробництво не могло обійтися без людської праці, то зараз багато процесів автоматизовано. Саме ці зміни ставлять перед HR-службами нові завдання та мотивують до несподіваних рішень і змушують працювати в умовах постійних ризиків та соціальних потрясінь.

Аналіз останніх досліджень і публікацій. Дослідження й аналіз діджіталізації сфери управління персоналом $є$ актуальними. Даній темі присвячено роботи таких вчених: В. Василівої [1], В. Жуковської [3], В. Куйбіди [5], Н. Нагибіної [8] та інших. Варто також зазначити, що еволюція управління персоналом спричинена впливом цифрових технологій все більше прискорюється. Це вимагає глибокого дослідження, оцінювання та визначення тенденцій діджіталізації HR-сфери.

Метою дослідження $є$ аналіз тенденцій діджіталізації та цифровізації управління персоналом, вивчення їх головних можливостей та ризиків.

Постановка завдання. Для досягнення поставленої мети визначено такі наукові завдання: провести аналіз процесів діджіталізації HR-служби, дослідити досвід вітчизняних та зарубіжних компаній у цьому процесі, надати рекомендації щодо використання діджітал-технології HR-процесів. Зокрема, є необхідність вивчення ризиків та можливостей упровадження різних інструментів діджіталізації в діяльність HR-служби.

Виклад основного матеріалу. В епоху 4.0 індустріальної революції саме технології надають будь-якій компанії можливість змінити власну бізнес-модель так, аби диференціюватися від усього світового ринку.

В Україні цифрова економіка почала розвиватися нещодавно, тому більшість компаній ще не готові впровадити нові системи. Але цифрова трансформація стає природним етапом розвитку управління HR-процесами. Треба зауважити, що діджіталізація HR-процесів істотно полегшує роботу служби управління персоналом, робить взаємодію з колегами, керівництвом і претендентами на посаду максимально ефективною та комфортною. У перспективі впровадження цифрових технологій у цю сферу - це вигідна інвестиція в розвиток бізнесу й підвищення продуктивності праці усіх відділів.

Можна вважати початком цифрової трансформації анонсований на Всесвітньому Економічному Форумі у Давосі (WEF), входження світу в 4.0 індустріальну революцію, де Клаус Швааб, засновник Форуму, сформулював певні тези про те, що 4th Industrial Revolution вже $є$ реальністю [7]. 
Наше століття часто називають «століттям людських ресурсів», оскільки для розвитку бізнесу слід не тільки його автоматизувати, а й організувати підтримку цього процесу людськими ресурсами. Тож основою розумного підприємства $є$ управлінські рішення для підвищення ефективності як того, що створює його інноваційність (наприклад, технології), так і тих, хто ці передові рішення використовує (керівники, персонал) [12].

Найближче майбутнє управління персоналом характеризується внутрішніми змінами, в яких основна увага буде приділена технології, а саме можливостям іiі використання для пошуку, залучення, об’єднання працівників і програмного забезпечення їх діяльності [4].

Нині важко уявити діяльність будь-якого підприємства без щоденного використання систем програмного забезпечення. Функціональні можливості інформаційної системи визначаються, з одного боку, загальними вимогами до певної системи та процесів управління, а, з іншого, - вимогами, що відображають специфіку певного підприємства. Необхідно автоматизувати не функції управління персоналом взагалі, а саме ті з них, які важливі на поточний момент і будуть потрібні найближчим часом. Надлишкові функції системи потребують використання додаткових ресурсів. Зазвичай, у першу чергу автоматизуються функції, що відповідають основним i найтрудомісткішим бізнес-процесам, наприклад, в управлінні персоналом - це: прийом на роботу, переведення, звільнення, оформлення відпусток тощо [10].

Дослідження свідчать про наявність значного розриву між тими компаніями, що активно впроваджують зміни, впевнено використовують нові ресурси й технології для удосконалення HR-процесів і такими, що займають позицію вичікування [6].

Діджіталізація HR-служби - це використання соціальних мереж, мобільних додатків, хмарних технологій, доповненої реальності. Це є новою платформою як для покращення роботи працівників, так і підвищення ефективності пошуку кандидатів на вакантну посаду. В той час, як розробники цифрових рішень забезпечують технічну складову HR-процесів, керівництву компаній та HR-департаменту необхідно будувати власні інтегровані стратегії та впроваджувати програми цифрового управління персоналом.

Ми провели соціологічне дослідження, в якому брало участь 124 працівники: 91,3\% працює в сфері HR, 4,2\% - працівники освітньої сфери, решта - студенти.

На основі дослідження ми визначили, що на даний момент 91,3\% працівників у сфері управління персоналом вважають, що автоматизація критично необхідна, 8,7\% утрималися від відповіді. Тобто сфері управління персоналом не уникнути автоматизації, оскільки завдяки цьому процесу продуктивність компаній зростає в рази.

Не зважаючи на всі страхи та ризики, компанії змушені розвивати й автоматизувати свої HR-процеси. На основі проведеного аналізу ми визначили, що $34,78 \%$ респондентів вважають, що українські компанії готові до впровадження автоматизації HR-процесів, 45,65\% - не готові, 10,87\% відповіли, що не знають, актуально це чи ні. Решта надала власні коментарі, де в основному зазначено, що лише великі національні та міжнародні компанії готові до автоматизації, а середні та малі ще не готові.

Компанії, які тільки починають використовувати цифрові технології в своїй діяльності, в першу чергу, лякаються їх знеособленості, а вже потім - складності й високої вартості.

Водночас, респонденти (рисунок 1), які вже встигли оцінити зручність цих інструментів, головними перевагами вважають скорочення витрат часу на типові кадрові процедури - 93,48\% опитаних, забезпечення прозорості кадрових процесів - 39,13\%, спрощення взаємодії співробітників - 47,83\%, інтеграцію 3 різними інформаційними 
системами та веб-ресурсами - 41,30\%, розвиток HR-бренду компанії - 17,39\%, економію коштів завдяки автоматизації-50\%, відстеження процесів адаптації, розвитку та професійного зростання співробітників - 54,35\%, деталізованість і точність даних 63,04\%, підвищення іміджу - 17,39\%.

Дуже влучно на конференції People Management 7 «Атланти для талантів» Рената Чучман, старший віце-президент і Global HR Business Partner компанії «SoftServe», сказала про цифоровізацію HR-процесів: «Цифрова реальність - у ній можна жити, а не виживати» [9]. Справді, наразі кожна компанія розуміє, що без навчання та розвитку неможливо бути успішним.

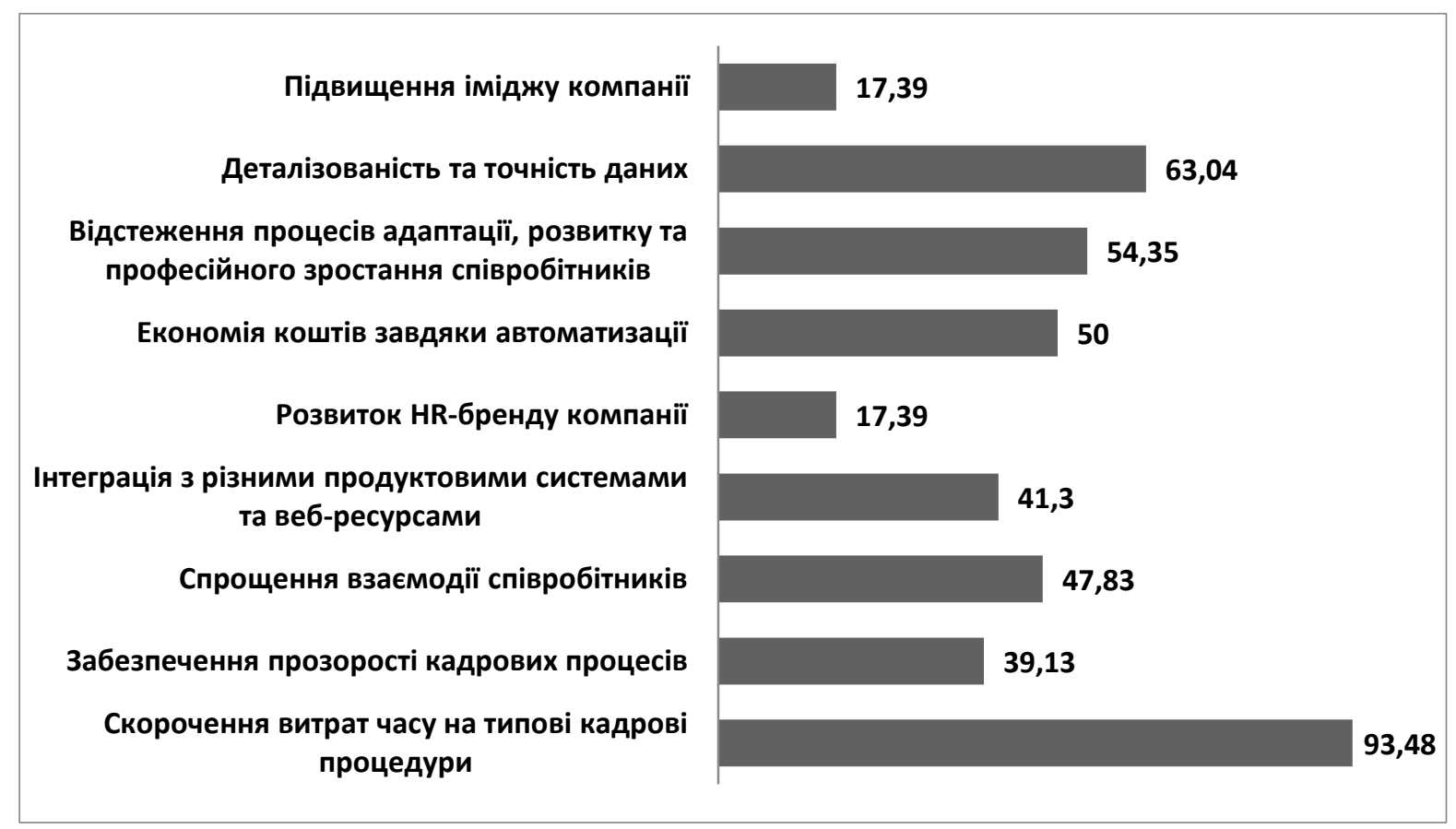

Рисунок 1. Результати відповідей на запитання: «Які, на вашу думку, основні переваги автоматизації HR-процесів?»

Figure 1. Answers to the question: «In your opinion, what are the main advantages of HR processes automation?»

На основі проведеного дослідження можемо сказати, що ринок праці не стоїть на місці, розвивається стрімкими темпами, а набір інструментів адаптації компанії до змін $\epsilon$ досить широкий. Нині в арсеналі HR-a $\epsilon$ надзвичайно велика кількість технологічних рішень, завдяки яким можна вирішувати різноманітні завдання: підбір, адаптацію, мотивацію, розвиток, навчання, комунікацію персоналу, оплату його праці, аналітику та багато іншого. За допомогою власного дослідження, ми дізналися про головні програмні рішення, якими користуються респонденти, або які використовуються в компанії.

Наведені результати (рисунок 2) показують, що лише 10,87\% респондентів не використовують жодних інструментів у своїй роботі. Тобто можна сказати, що розуміння неминучості змін $\epsilon$, однак потрібні подальші кроки для адаптації та розвитку управління персоналом до сучасних реалій.

Як бачимо на рисунку 2, переважають HRM-системи, соціальні мережі, та джобсайти, оскільки це ті ресурси, без яких наразі неможливо уявити роботу HR-служби. Джоб-портали до цього часу $є$ основним джерелом пошуку роботи для більшості 
професіоналів і розміщення вакансій. Фактично всі закордонні джоб-сайти основним джерелом свого доходу вважають публікацію вакансій (по суті вони є зручними джоббордами онлайн). Продаж доступу до баз даних кандидатів не $є$ їх значущим продуктом, тому що активний розвиток професійних соціальних мереж не дає їм можливість створити конкурентоспроможний продукт 3 власної бази резюме. До успішних професійних мереж крім LinkedIn належать Viadeo.com (у першу чергу в франкомовних країнах) i Xing.com (у країнах з переважанням німецької мови - Німеччина, Австрія, Швейцарія). За допомогою соціальних мереж можна не лише шукати персонал та розміщувати вакансії, а й оцінювати кандидатів. Наприклад, простий перегляд сторінки людини може надати базову інформацію про неї: вік, освіту, хобі, фото, спираючися на які рекрутер може визначити підходить даний претендент на посаду, чи співпадають його цінності та стиль життя з цінностями компанії.

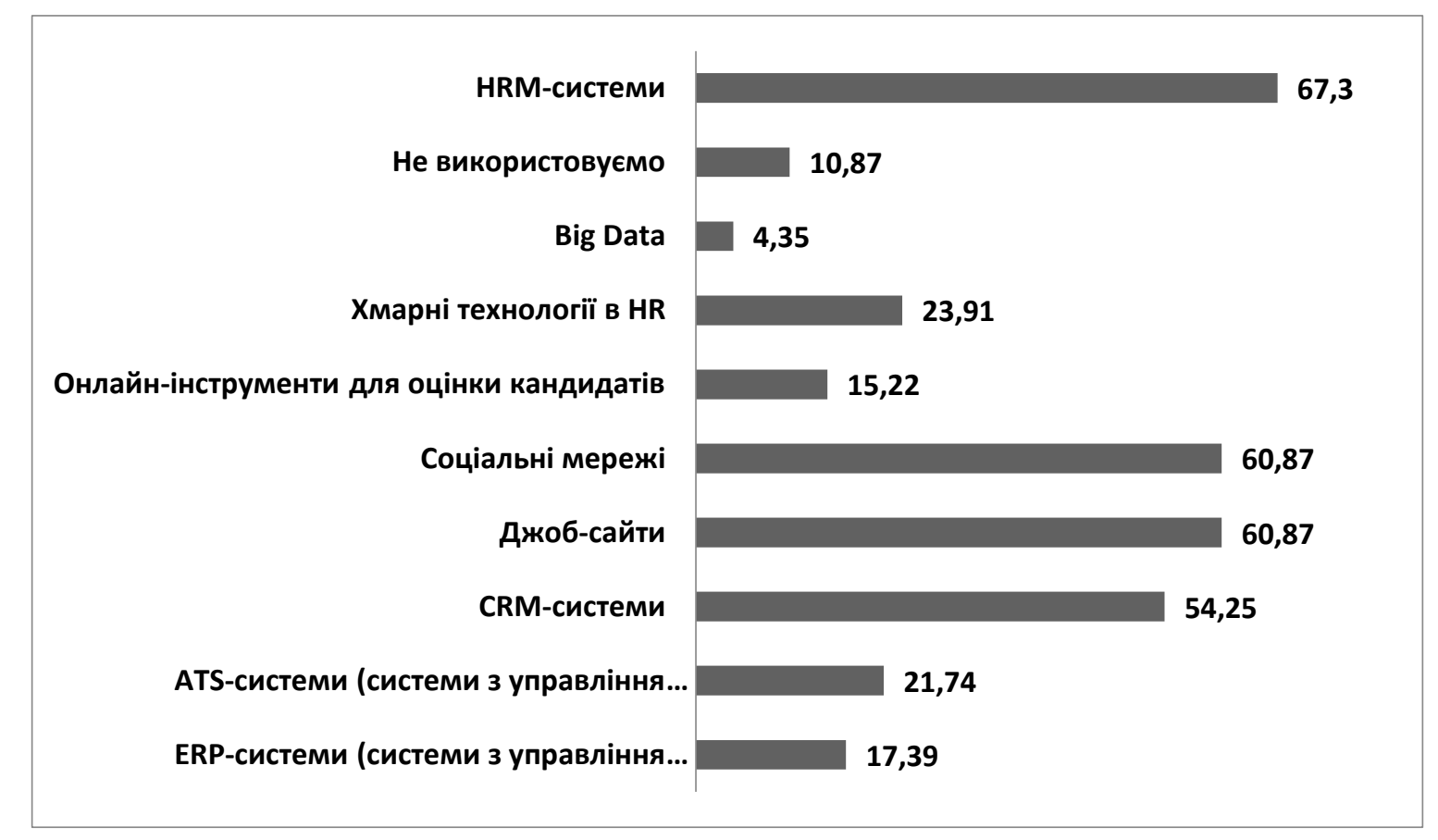

Рисунок 2. Результати відповідей на запитання: «Які HR digital-інструменти використовує ваша компанія?»

Figure 2. Answers to the question: «What HR digital tools does your company use?»

У свою чергу, HRM-системи спрямовані на звільнення фахівців з управління персоналу від щоденних монотонних і трудомістких завдань, зробивши їх життя простішим та яскравішим. Кожне рішення має свою специфіку й відрізняється одне від одного, однак їх усіх об'єднує автоматизація HR-процесів. Наразі навіть найпростіші системи дають змогу вести бази кандидатів і співробітників, облік відпусток, лікарняних та інших видів відсутності, проводити адаптацію нових працівників за допомогою різноманітних інтегрованих додатків, створювати індивідуальні плани розвитку для співробітників, розміщувати вакансії на різних джоб-порталах, проводити аналітику й оцінювати ефективність працівників.

Отже, HR-процеси нині автоматизуються за допомогою різноманітних цифрових рішень. У нашому досліджені (рисунок 3) були досліджені різні програми та системи, починаючи з програми для проведення відеоконференцій «Zoom» і закінчуючи HRMсистемами, такими, як «SAP HCM» та «Oracle HCM». Провівши дослідження, ми 
виявили, що 62,3\% опитаних використовують кілька систем. Для обліку, адміністрування та розрахунку 3 персоналом значна кількість респондентів використовують програму «1С» як потужний інструмент для реалізації кадрової політики підприємства, а як CRM-систему використовують «Bitrix 24»- це набір з п’яти інструментів, який допомагає керівникові вибудувати в своєму колективі ефективну роботу, проводити ділове спілкування між співробітниками, здійснювати облік і контроль робочого часу, вести корпоративний чат, автоматизувати бізнес-процеси. Набуває свого поширення програмне забезпечення «Hurma». У ньому здійснюються усі процеси рекрутингу, HR та OKR в одній системі, а саме: робота 3 вакансіями та кандидатами; планування дзвінків по телефону та Skype, інтерв'ю та тестові завдання; керування тестовим періодом та його оцінювання; процес оцінювання; отримання зручних повідомлень про важливі події в житті компанії; управління цілями і ключовими результатами (OKR). Це ті програми, які нині використовуються найчастіше. Вони $€$ привабливими завдяки їх простоті, можливості інтеграції з іншими системами та через невисоку ціну. 9,3\% респондентів вказали, що використовують програми, які були розроблені для внутрішнього користування власними IT-спеціалістами.

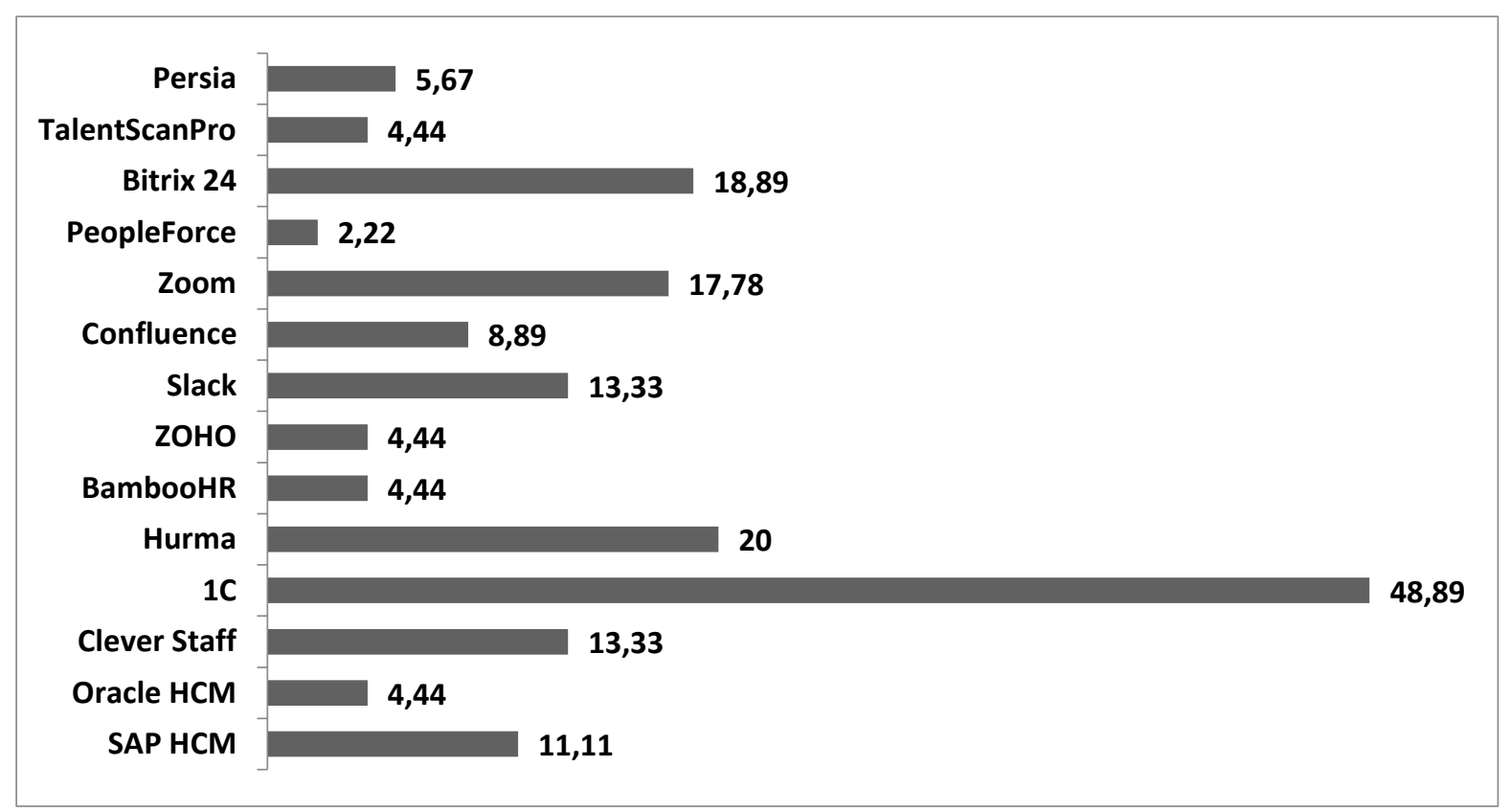

Рисунок 3. Результати відповідей на запитання: «Якими програмними продуктами користується ваша компанія?»

Figure 3. Answers to the question: «What software products does your company use?»

Проведене авторами опитування дозволило проаналізувати цілі автоматизації HR-процесів у компанії. Для 42\% респондентів важливими були функціональні можливості рішень, 28\% зазначило, що вони приймали рішення на основі простоти й легкості впровадження, для 15,5\% першочерговим показником була ціна, 7,5\% вважають, що саме надійність є одним із найважливіших критеріїв, 7\% респондентів віддали перевагу цілодобовій підтримці.

Одним із найважливіших питань, яке стосується кожного HR: «Чи зможуть технології замінити роль HR-служби в компанії?» Проведене дослідження показує, що 62,55\% респондентів вважають, що автоматизація та діджіталізація не зможе замінити 
HR-фахівців у компанії, 23,91\% - що можуть, 4,35\% - вагаються при відповіді на це питання, а решта пророкує, що наступні 20-30 років професії HR-a нічого не загрожує. Нині лідером цифровізації в HR $є$ напрям рекрутменту, а саме процеси пошуку, відбору та найму кандидатів, далі- навчання i розвиток співробітників. За допомогою цифровізації процесу рекрутингу полегшується повне ведення бази кандидатів i проведення кандидатів через всі етапи найму. Провідні програми мають можливість опрацьовувати резюме практично з будь-яких джерел (текстові файли у форматі .docx, .odt, .rtf, .csv, .txt та ін.), що істотно заощаджує час рекрутера. Трішки відстає, але знаходиться в зоні активного зростання такий цифровий напрям як HR-аналітиканадання керівництву та співробітникам організації інформації про власні операції, яка може допомогти в ефективному управлінні компанією. Крім того, вона надає моделі для прогнозування різних способів, якими організація може отримати оптимальну віддачу від інвестицій (ROI) у свій людський капітал. Існують інструменти, які можна використовувати для автоматичного опрацювання та завантаження інформації в процесі HR-аналітики. Це, наприклад, використання IMB Websphere Data Stage i Cognos Data Manager або Microsoft SQL Server Integration Services є одними з найпопулярніших опцій. Хоча співробітники без технічної освіти можуть використовувати ці платформи, але корисно залучити IT-відділ до допомоги. Стають актуальними системи гейміфікації, тобто ненав'язливого, без будь-яких гасел стимулювання бажаної поведінки співробітників через гру. Цей процес реалізується особливо в молодих компаніях та стартапах за допомогою ігрових методик, реалізованих на програмних продуктах та вебдодатках. Розрізняють зовнішню та внутрішню гейміфікацію. Перша спрямована на залучення споживачів та потенційних клієнтів і в результаті- підвищення впізнання бренду та зростання доходів компанії. Друга спрямована на підвищення ефективності роботи компанії, мотивування та підвищення лояльності працівників. За цією класифікацією гейміфікація в HR-менеджменті потрапляє у групу внутрішньої гейміфікації. Проте у випадках застосування ігротехнік у HR-функціях виокремити вплив останніх на окрему спеціальну функцію управління людськими ресурсами організації досить важко, оскільки вплив є багатовекторним. Проте саме рекрутмент нині має для бізнесу найбільше значення серед усіх HR-інструментів [11, 13].

Розглянемо кілька прикладів використання діджітал-технології HR-процесів у роботі вітчизняних та міжнародних компаній (таблиця 1).

Таблиця 1. Використання діджітал-технологї̈ HR-процесів вітчизняними та міжнародними компаніями

Table 1. The use of digital technology of HR processes by national and international companies

\begin{tabular}{|c|c|c|}
\hline Назва компанії & Назва технології & Характеристика результату \\
\hline 1 & 2 & 3 \\
\hline Salateira & $\begin{array}{l}\text { Співбесіда за } 90 \text { секунд за допо- } \\
\text { могою Job Bot y Telegram, Viber чи } \\
\text { Facebook }\end{array}$ & $\begin{array}{l}\text { Компанія піклується про їхній особистий час } \\
\text { та допомагає перемогти страх проходження } \\
\text { першої співбесіди із менеджером } 3 \text { персо- } \\
\text { налу. Має вигоди й для самої компанії: } \\
\text { збільшення зовнішнього кадрового резерву за } \\
2,5 \text { місяця на } 2767 \text { осіб та зниження вартості } \\
\text { залучення одного кандидата у } 2 \text { рази }\end{array}$ \\
\hline
\end{tabular}


Закінчення таблиці 1

\begin{tabular}{|c|c|c|}
\hline 1 & 2 & 3 \\
\hline SoftServe & $\begin{array}{l}\text { Фідбек опитування. Кожна сесія - } \\
\text { це окремий раунд, після якого } \\
\text { підбиваються підсумки і вистав- } \\
\text { ляються оцінки. Через } 4 \text { місяці } \\
\text { відбувається наступний раунд- } \\
\text { нова сесія опитування й нові } \\
\text { оцінки. У перерві між раундами } \\
\text { відбувається активна комунікація } \\
\text { щодо статусу та планів впрова- } \\
\text { дження інновацій }\end{array}$ & $\begin{array}{l}\text { Працівники завжди у курсі того, що } \\
\text { відбувається в діяльності компанії і можуть } \\
\text { поставити свої запитання та залишити } \\
\text { коментарі. Дозволило збільшити кількість } \\
\text { лояльних до компанії працівників (promoters) } \\
\text { та зменшити кількість тих, хто був } \\
\text { незадоволений певними аспектами роботи } \\
\text { (detractors) }\end{array}$ \\
\hline Датагруп & $\begin{array}{l}\text { Єдиний простір для обміну ідеями, } \\
\text { взаємодії та активної самореаліза- } \\
\text { ції співробітників - DataLab - } \\
\text { портал системи дистанційного } \\
\text { навчання. Мета DataLab - не } \\
\text { змушувати навчатися, а формувати } \\
\text { у співробітників осмислену потре- } \\
\text { бу в саморозвитку } \\
\end{array}$ & $\begin{array}{l}\text { Співробітники компанії отримали можли- } \\
\text { вість самостійно впливати на матеріали, за } \\
\text { якими вони навчаються, задавати теми для } \\
\text { обговорень, формувати ком’юніті, яке їм } \\
\text { необхідно }\end{array}$ \\
\hline ПриватБанк & $\begin{array}{l}\text { Онлайн-платформа для практики, } \\
\text { що забезпечує високу якість } \\
\text { підготовки практикантів та } \\
\text { задовольняє потреби студентів } \\
\text { вишів і банку }\end{array}$ & 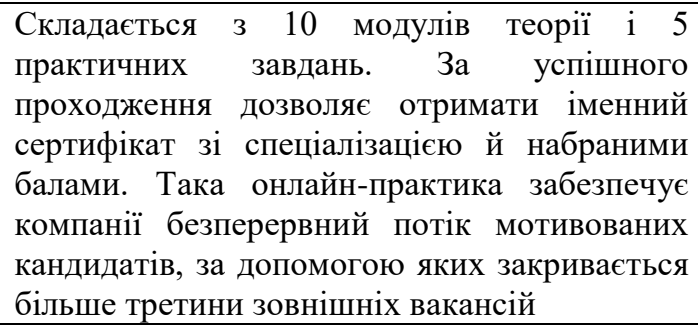 \\
\hline Deloitte & $\begin{array}{l}\text { Чат-бот D.TalCa (Deloitte Talent } \\
\text { Candidate), який підбирає та } \\
\text { пропонує вакансію, що найбільш } \\
\text { підходить кандидату. Використан- } \\
\text { ня онлайн-ігр для інтенсифікації } \\
\text { інноваційного процесу }\end{array}$ & $\begin{array}{l}\text { Проводить первинне інтерв’ю навіть вночі, } \\
\text { рекомендує пошукачам вакансії в «Deloitte», } \\
\text { знайомить } 3 \text { компанією, іï історією та } \\
\text { подіями. Використання в навчанні багато- } \\
\text { користувацьких онлайнових рольових ігр } \\
\text { дозволило підвищити залученість персоналу } \\
\text { в програми навчання. Інтелектуальна гра } \\
\text { привертає увагу працівників та дозволяє їм } \\
\text { обговорити деталі нового процесу й } \\
\text { дослідити нові варіанти й можливості }\end{array}$ \\
\hline
\end{tabular}

*Побудовано авторами $[2,11,14]$.

Але не можна визначити універсальні діджітал-технології та інструменти для всіх організацій. Для кожної окремої організації можуть застосовуватися тільки ті, які корисні в умовах іiі розвитку та існування. Необхідно поєднувати різні підходи й методи. Це дозволить організації оптимізувати HR-процеси підбору персоналу, підвищити ефективність і конкурентоспроможність компанії.

Варто також акцентувати увагу на можливостях, які надає діджіталізація та цифрова трансформація HR-служби:

- застосування інтегрованих мобільних додатків й автоматизація HR-процесів;

- застосування VR-технологій;

- цифрова інтеграція з хмарними системами;

- $\quad$ HR-аналітика та Big Data;

- штучний інтелект.

Завдяки спільній цифровій платформі працівники можуть відстежувати та управляти інформацією в режимі реального часу. Ця ж інформація доступна менеджерам, які завжди можуть отримати до неї доступ, просто скориставшись 
смартфоном. Робочі процеси стають прозорішими і зрозумілішими. Співробітники можуть відслідковувати свої успіхи та підходити до побудови своєї кар'єри стратегічно. Ці можливості є невід'ємними чинниками «розумного» підприємства. HR-служба створює стратегію й консультує щодо того, як правильно скористатися цими перевагами. Водночас діджіталізація вимагає грошових витрат і часу. Тому, на нашу думку, найголовніше - це прийняти рішення впроваджувати цифрові технології, готовність змінювати свої звичні процеси та прийняти на себе ризики. У будь-якому випадку, цифровізація поширюється в усіх сферах суспільного життя й ігнорувати ці процеси неможливо. Важливими стають особистісні якості самого HR-a, який повинен визначити своє місце і роль у процесі діджіталізації HR-сфери.

Висновки. Кожен HR повинен перш за все визначити свою роль, яка допоможе керівництву та працівникам швидко трансформуватися й адаптуватися до цифрового способу мислення. Обов'язково необхідно удосконалити та модернізувати традиційну систему HR-рішень, а краще замінити іiї на інтегровану хмарну платформу, що створить надійну цифрову інфраструктуру підприємства. На нашу думку, саме від HR-служби залежить продуктивність праці колективу, й як наслідок - компанії в цілому. Сучасний HR за допомогою різноманітних цифрових рішень створює для працівників середовище ефективної та продуктивної праці. Досвід проведення провідними компаніями діджіталізації HR-функцій показує свою ефективність. Однак імплементація різних іiі методів і підходів, а також оцінювання їх ефективності потребує подальшого дослідження.

Conclusions. At present every HR should first and foremost define the role that will help executives and employees to transform and adapt quickly to the digital way of thinking. It is necessary to improve and upgrade traditional HR-solution system, or even better to replace it with the integrated cloud platform creating reliable digital enterprise infrastructure. In our opinion, it is HR-service that determines the productivity of the team and, as a result, of the company as a whole. By means of various digital solutions, modern HR creates the environment for employees where they work efficiently and productively. The leading companies experience in HR functions digitization proves its effectiveness. However, the implementation of its various methods and approaches, as well as the evaluation of their effectiveness, requires further investigations.

\section{Список використаної літератури}

1. Василів Б. В. Інформаційні системи менеджменту персоналу: навч. посіб. Рівне: НУВГП, 2014. $148 \mathrm{c}$.

2. До «Делойт» в Україні працевлаштувався бот-рекрутер. URL: https://www2.deloitte.com/ua/uk/ pages/press-room/press-release/2018/chatbot-dtalca-at-deloitte-ukraine.html.

3. Жуковська В. М. Цифрові технології в управлінні персоналом: сутність, тенденції, розвиток. Науковий вісник Міжнародного гуманітарного університету. 2017. № 2. С. 13-17.

4. Кравчук О. І. Цифрова компетентність менеджера з персоналу. Соціально-трудові відносини: теорія та практика. 2018. № 1. С. 172-191.

5. Куйбіда В. С., Петроє О. М., Федулова Л. І., Андрощук Г. О. Цифрові компетенції як умова формування якості людського капіталу: аналіт. зап. Київ: НАДУ. 2019. 28 с.

6. Майбутне HR. Що відрізняє пасивного спостерігача від активного учасника? URL: https://assets.kpmg/content/dam/kpmg/ru/pdf/2019/04/ru-ru-future-of-hr-2019.pdf.

7. Meta-Digital Accounting in the Context of Cloud Computing/Alexandru Tugui. Encyclopedia of Information Science and Technology. Third Edition. 2015.

8. Нагибина Н. I., Щукина А. A. HR-digital: цифровые технологии в управлении человеческими ресурсами. Науковедение. 2017. T. 9.17 c. URL:http://naukovedenie.ru/PDF/24EVN117.pdf.

9. Підсумки бізнес-конференції People Management 7: Атланти для талантів. URL: https://kagroup.ua/\%D0\%B8\%D1\%82\%D0\%BE\%D0\%B3\%D0\%B8-\%D0\%B1\%D0\%B8\%D0\%B7\%D0 \%BD\%D0\%B5\%D1\%81\%D0\%BA\%D0\%BE\%D0\%BD\%D1\%84\%D0\%B5\%D1\%80\%D0\%B5\%D0\%B $\mathrm{D} \% \mathrm{D} 1 \% 86 \% \mathrm{D} 0 \% \mathrm{~B} 8 \% \mathrm{D} 0 \% \mathrm{~B} 8-$ people-management-7-\%D0\%B0\%D1\%82\%D0\%BB\%D0\%B0\%D0\%B D\%D1\%82\%D1\%8B.html. 
10. Рудакова С. Г., Щетініна Л. В., Марчук С. В. Кадрове адміністрування: сучасні тенденції та досвід України у використанні програмного забезпечення. Бізнес Інформ. 2016. № 3. С. 250-254.

11. Середа Г. В. Гейміфікація в менеджменті персоналу: зарубіжний та український досвід. Економіка і організація управління. 2017. Вип. 4. C. 216-223. URL: http://nbuv.gov.ua/UJRN/eiou_2017_4_22.

12. Фактор успіху: як HR може сприяти формуванню розумного підприємства. URL: https://prohr.rabota.ua/faktor-uspihu-yak-hr-mozhe-spriyati-formuvannyu-rozumnogo-pidpriyemstva/.

13. Цифровий HR: революція на підході. URL: https://www.computerworld.ru/articles/Tsifrovoy-HRrevolyutsiyana-podhode.

14. Чому ваша компанія має діджіталізуватися i 4 приклади того, як це робити. URL: https://kiev.hh.ua/article/25430?utm_source=telegram\&utm_medium=post\&utm_campaign=recrutoria.

\section{References}

1. Vasiliv B. V. Informacijni sistemu menedzhmentu personalu. Personnel management information system: navch. posib. Rivne: NUVGP. 148 p. [In Ukrainian].

2. Do "Delojt" v Ukrajini pracevlashtuvavsja bot-rekruter. A bot recruiter has been employed in Deloitte in Ukraine. URL: https://www2.deloitte.com/ua/uk/pages/press-room/press-release/2018/chatbot-dtalca-atdeloitte-ukraine.html.

3. Zhukovs'ka V. M. Cyfrovi texnolohiji v upravlinni personalom: sutnist', tendenciji, rozvytok. Digital technologies of hr management: satisfaction, trends, development. Naukovyj visnyk Mizhnarodnogo gumanitarnogo universytetu. International Humanitarian University Herald. Economics and Management. 2017. Vol. 2. No. 27. P. 13-17. [In Ukrainian].

4. Kravchuk O. I. Cyfrova kompetentnist' menedzhera $\mathrm{z}$ personalu. HR-manager digital competency. Social'no-trudovi vidnosyny: teorija ta praktyka. Social and labour relations: treory and practice. 2018. Vol. 1. No. 15. P. 172-191. [In Ukrainian].

5. Kujbida V. S., Petroje O. M., Fedulova L. I., Androshhuk G. O. Cyfrovi kompetenciji jak umova formuvannja jakosti ljuds'koho kapitalu: analit. zap. Digital competence as a condition for the formation of human capital quality: analytical query. Kyiv: NADU, 2019. 28 p. [In Ukrainian].

6. Majbutnje HR. Shho vidriznjaje pasyvnogo sposterigacha vid aktyvnogo uchasnyka? The future of HR. What distinguishes a passive observer from an active participant? URL: https://assets.kpmg/content/ dam/kpmg/ru/pdf/2019/04/ru-ru-future-of-hr-2019.pdf.

7. Meta-Digital Accounting in the Context of Cloud Computing/Alexandru Tugui. Encyclopedia of Information Science and Technology. Third Edition. 2015.

8. Nagibina N. I., Shchukina A. A. HR-Digital: tsifrovye tekhnologii v upravlenii chelovecheskimi resursami. HR-Digital: digital technologies in human resource management. Internet-zhurnal "Naukovedenie". Internet journal "Science studies", 2017. Vol. 9. No. 1. URL: http://naukovedenie.ru/ PDF/24EVN117.pdf. [In Russian].

9. Pidsumky biznes-konferenciji People Management 7: Atlanty dlja talantiv. Business Conference People Management 7 Results: Atlantes for Talent. URL: https://kagroup.ua/\%D0\%B8\%D1\%82\%D0\%BE\%D0\%B3\%D0\%B8-\%D0\%B1\%D0\%B8\%D0\%B7\%D0 $\% \mathrm{BD} \% \mathrm{D} 0 \% \mathrm{~B} 5 \% \mathrm{D} 1 \% 81 \% \mathrm{D} 0 \% \mathrm{BA} \% \mathrm{D} 0 \% \mathrm{BE} \% \mathrm{D} 0 \% \mathrm{BD} \% \mathrm{D} 1 \% 84 \% \mathrm{D} 0 \% \mathrm{~B} 5 \% \mathrm{D} 1 \% 80 \% \mathrm{D} 0 \% \mathrm{~B} 5 \% \mathrm{D} 0 \% \mathrm{~B}$ D\%D1\%86\%D0\%B8\%D0\%B8-people-management-7-\%D0\%B0\%D1\%82\%D0\%BB\%D0\%B0\%D0\%B D\%D1\%82\%D1\%8B.html.

10.Rudakova S. G., Shchetinina L. V., Marchuk S. V. Kadrove administruvannja: suchasni tendenciji ta dosvid Ukrajiny u vykorystanni programnogo zabezpechennja. HR Administration: Current Trends and the Experience of Ukraine in the Software Use. Biznes Inform. Business-inform. 2016. No. 3. P. 250-254. [In Ukrainian].

11. Sereda G. V. Gejmifikacija v menedzhmenti personalu: zarubizhnyj ta ukrai'ns'kyj dosvid. The gamification in personnel management: foreign and Ukrainian experience. Ekonomika i organizacija upravlinnja. Economics and organization of managment. 2017. Vol. 4. P. 216-223. URL: http://nbuv. gov.ua/UJRN/eiou_2017_4_22. [In Ukrainian].

12. Faktor uspihu: jak HR mozhe spryjaty formuvannju rozumnogo pidpryjemstva. Success Factor: How HR can help shape a smart business. URL: https://prohr.rabota.ua/faktor-uspihu-yak-hr-mozhe-spriyatiformuvannyu-rozumnogo-pidpriyemstva/.

13. Cyfrovyj HR: revoljucija na pidhodi. Digital HR: Revolution is near. URL: https://www. computerworld.ru/articles/Tsifrovoy-HR-revolyutsiyana-podhode.

14. Chomu vasha kompanija maje didzhytalizuvatys' i 4 pryklady togo, jak ce robyty. Why your business needs to be digitized and 4 examples of how to do it. URL: https://kiev.hh.ua/article/25430? utm_source=telegram\&utm_medium=post\&utm_campaign=recrutoria. 